\title{
Livestock breeding for sustainability to mitigate global warming, with the emphasis on developing countries
}

\author{
M.M. Scholtz ${ }^{1,2 \#}$, A. Maiwashe ${ }^{1,2}$, F.W.C. Neser ${ }^{2}$, A. Theunissen ${ }^{3}$, W.J. Olivier ${ }^{4}$, \\ M.C. Mokolobate ${ }^{1,2}$ \& J. Hendriks ${ }^{1,2}$ \\ ${ }^{1}$ ARC-Animal Production Institute, Private Bag X2, Irene, 0062, South Africa; ${ }^{2}$ University of the Free State, PO Box \\ 339, Bloemfontein, 9300, South Africa; ${ }^{3}$ Northern Cape Department of Agricultural, Land Reform and Rural \\ Development, Private Bag X9, Jan Kempdorp 8550, South Africa; ${ }^{4}$ Grootfontein Agricultural Development Institute, \\ Private Bag X529, Middelburg EC, 5900, South Africa
}

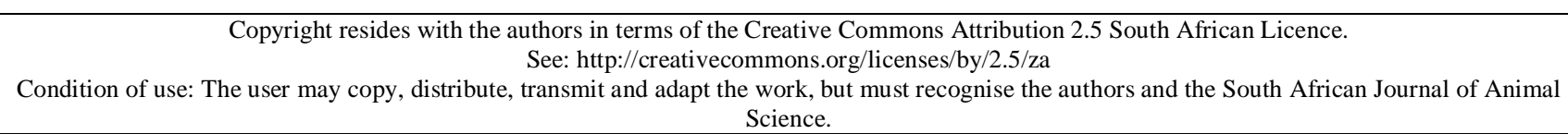

\begin{abstract}
Global warming is predicted to have a profound effect on livestock production in developing countries. An improved understanding of the adaptation of livestock to such changing production environments is thus important, but the measurement of adaptation is complex and difficult. Proxy-indicators for adaptation, such as reproductive and production traits, however, can be used. Livestock industries have a responsibility to reduce the release of greenhouse gases (i.e. the carbon footprint) and water use (i.e. the water footprint). An effective way of decreasing the carbon and water footprints from livestock is to reduce livestock numbers and increase the production per animal. Increased production generates less greenhouse gas emissions per unit of livestock product. Proper definition of breeding objectives and trait definition is essential in implementing efficient breeding systems to cope with climate change. Sophisticated statistical models continue to support animal breeding and improvement, especially with respect to production traits. Traits linked to fertility and survival are still problematic and appropriate genetic technology to properly characterize these traits needs to be developed. Gene or marker-assisted selection may play an important role in selection for disease and parasite resistance or tolerance, since it is generally difficult to measure these traits directly. Strategies that utilize breeding values derived from genomic analyses may speed up the process of breeding animals with higher and more efficient production and that are adapted to the changing environments as a result of global warming. However, both genetic and epigenetic controls influence genetic expression and should be taken into account when formulating breeding programmes. Subsistence farmers keep livestock for multiple purposes and the formulation of breeding objectives/strategies will have to consider these dynamics.
\end{abstract}

Keywords: Breeding objectives, epigenetics, genomics, production systems, quantitative breeding, residual efficiency traits

\# Corresponding author: GScholtz@arc.agric.za

\section{Introduction}

Global warming is expected to have more extreme effects on developing countries of the southern hemisphere than on countries of other continents (Scholtz et al., 2013a). The anticipated global warming will change southern hemisphere environments and vegetation (Scholtz \& Theunissen, 2010; Scholtz et al., 2013a). The effects of global warming on sustainable animal production are related to the consequences of changes in ambient temperature (heat stress, nutritional stress, lowered production/reproduction), rainfall, humidity, solar radiation, altered patterns of animal and plant diseases (threat of new disease, frequency of existing diseases), nutritional value of cultivated and natural pastures and change in pasture composition (growth, yield and stocking rate) and adaptation of animals to production environments (Scholtz et al., 2011; Scholtz et al., 2012). Ambient temperature is the factor that has the largest direct effect on livestock 
production, and nutritional stress has the largest indirect effect on the grazing animal in the tropics and subtropics (Linington, 1990).

The anticipated change discussed above will have a negative effect on livestock production environments, which will influence political, economic and social issues (Scholtz et al., 2013b). An improved understanding of the adaptation of livestock to their production environments is therefore important, but adaptation is a complex trait and thus difficult to measure. Fortunately, several proxyindicators for adaptation are available such as reproductive, production and health traits. Because of global warming, livestock in developing countries will have to adapt to higher ambient temperatures, a lower nutritional value of grasses in some cases, and expansion of the occurrence of parasites and diseases, especially ticks and tick-borne diseases (Scholtz et al., 2011). With such challenges, proper trait definition and matching genotype with production environment will become crucial. The selection of animals and genotypes that are better adapted to the production system, including heat stress, is possible, and should be pursued to ensure sustainable production in warmer climates. This will require innovative breeding strategies.

From the onset of domestication animals have knowingly or unknowingly been selected for the production of food and other purposes. During the past two centuries, an important part of livestock breeding was the deliberate selection of animals to improve breeds or strains (Simm et al., 1996). This has led to a considerable increase in the production levels of most agricultural species (Rauw et al., 1998). Falconer \& Mackay (1996) and Shrestha \& Fahmy (2005) stated that the selection of replacement animals from parents with outstanding genetic merit would lead to accelerated genetic response for the trait under selection.

Livestock are unique in the sense that they not only suffer from climate change, but also contribute to climate change through the release of greenhouse gases (GHG). The impact of global warming and continued uncontrolled release of GHG thus has a twofold implication for the livestock industry, and consequently food security (Scholtz et al., 2013a).

The livestock industries have a responsibility to reduce the release of GHG (i.e. the carbon footprint) and water use (i.e. the water footprint) of livestock production. An effective way of diminishing the carbon and water footprints from livestock is to reduce livestock numbers and increase the production per animal, thereby improving their productivity. Increased production generates less GHG emission per unit of livestock product (Capper, 2013). Production efficiency can be improved through breeding, and there is sufficient genetic variation in the livestock genetic resources of developing countries to facilitate breeding for improved production efficiency. GHG emissions per unit livestock output in developing countries can be reduced substantially if the comparatively low growth and efficiency (both pre- and post-weaning) and fitness (reproductive rate and longevity) can be addressed (Scholtz \& Bester, 2010). Alternative traits to improve production efficiency through selection should also be investigated.

This paper gives an overview of livestock breeding, and attempts to identify sustainable breeding strategies in anticipation of climate change.

\section{Animal recording}

Recording the production performance of animals forms the backbone of any breeding or improvement programme. Improvement will be slow for specific traits if they are not measured and recorded. African countries such as Namibia, South Africa and, to a lesser extent, Kenya have wellorganized recording and improvement programmes (Scholtz et al., 2013b). However, in many developing countries, the infrastructure and systems for conventional animal improvement are lacking, and the early speculations that marker-assisted selection would provide a quick solution in the absence of such systems have been proven incorrect (Van der Westhuizen et al., 2005). In addition, production recording in many developing countries is difficult since the breeding objectives may include many traits, some of which cannot easily be measured or quantified.

A scientifically based central database has many advantages for South Africa and other developing countries that want to compete globally and at the same time to ensure local capacity in research, development and a knowledgeable industry (Van der Westhuizen, 2002). Public support is more crucial in developing countries than in the developed countries, where animal recording systems are administered privately. Such public support is usually channelled through research and academic institutions and incentives for farmers to participate in national recording schemes. Sustained public support is important 
since recording schemes usually benefit users, primary beneficiaries and consumers, as well as a host of other groups, including government (Van der Westhuizen et al., 2005).

\section{Quantitative breeding}

Sophisticated, high-dimensional, statistical models have been developed and are being applied in the field of quantitative animal breeding (Gianola, 2006). Breeding values (EBVs) are estimated in routine genetic evaluations, which are subsequently used in selecting breeding animals. The challenge now is to identify fixed and random effects in quantitative breeding technology that account for spatial and temporal variation in production environments for use in these genetic evaluations. The estimation of separate EBVs for different production environments may even be necessary in extreme cases (Neser et al., 2008).

This has resulted in the development of the concept of physiological breeding values (PhBV) in an attempt to deal with the new dimensions brought about by climate change. The main difference between PhBVs and EBVs is in the way in which genetic potential is defined (Bourdon \& Enns, 1998). In contrast to conventional breeding value predictions, $\mathrm{PhBVs}$ are not population dependent and do not rely on the genetic merit of the population in which they were evaluated, whereas conventional breeding values depend on the genetic merit of the population. For example, in Neser et al. (2008), Bonsmara bull 4492 has an EBV of $+8.29 \mathrm{~kg}$ for weaning weight in environment 3 and an EBV of $+19.20 \mathrm{~kg}$ in environment 4 . However, his $\mathrm{PhBV}$ would remain the same, for example $245 \mathrm{~kg}$, regardless of the environmental grouping in which the bull was evaluated (Scholtz et al., 2010). PhBVs are independent of the environment, and they do not change under different environmental conditions. They predict performance potential in the optimal environment. $\mathrm{PhBV}$ s alone cannot predict the phenotype, and must be combined with information about the physical environment and management, in order for it to be translated into performance measures through simulation models. In spite of the potential advantages of PhBVs, they have not received much attention from researchers.

It is only in growth and production traits that quantitative breeding technology has succeeded in predicting breeding values that are not problematic. Traits linked to fertility and survival (age at first lambing/calving, lambing/calving interval, stayability, lambing/calving tempo) are all influenced significantly by the environment, management and arbitrary decisions taken by breeders or scientists. The appropriate quantitative breeding technology to properly characterize most of these traits still needs to be developed or refined (Scholtz et al., 2010).

More recent innovations include methods to identify and genotype single nucleotide polymorphism (SNP) markers on a large scale. These new technologies will lead to the development of new applications such as methods to genetically evaluate and select animals, based on their genomic estimated breeding value (GEBV) (Hayes et al., 2009). An important prerequisite is the establishment of resource (reference) populations for local use and different environments, which may be costly (Meuwissen et al., 2001; VanRaden, 2008; VanRaden et al., 2009).

There are large differences between breeding livestock for the subtropics/tropics and for temperate areas. In addition to the normal fitness, growth and production traits, other traits should be considered, since livestock in subtropical and tropical environments are subjected to numerous stress factors (Prayaga et al., 2006) for example parasites (tick and tick-borne diseases, internal parasites, flies); seasonally poor nutrition; high temperatures or high daily temperature variations; humidity (both high and low); and temperament. These factors are exaggerated by extensive production systems.

\section{Breeding objectives/proper trait definition}

Ponzoni (1986) suggested that maximizing the return on investment must be the aim of genetic improvement programmes, and that selection and breeding objectives must be set accordingly. This means that the breeding objectives should be directed at improving the traits that will have an effect on production and revenue of product sales (Ponzoni, 1992; Holst, 1999). However, normally both tangible and intangible traits, as well as only the easily measureable traits, are included in the traditional ruminant breeding systems (Kosgey \& Okeyo, 2007).

Clear definition of breeding objectives and the implementation of efficient breeding systems should form the basis for optimal utilization of genetic resources as recommended by the Food and Agriculture Organization (FAO) of the United Nations (FAO, 1998). Most animal breeding programmes lack basic definition of breeding objectives. In a breeding objective or goal, the trait under consideration is the end - 
what should be achieved. Decisions about such a trait are based purely on the end product, not on whether it is difficult or easy to measure or whether there may be problems in selecting for it. The next phase is to identify the selection criteria, which are the traits that should be used in selecting animals (Mokolobate et al., 2013a). Traits in the selection criteria should be correlated with the traits in the breeding objective, easily measurable and heritable.

Until now, most measurements to improve production in developing countries, and many other parts of the world, are per individual (milk production, fibre production, weaning weight, calving interval, growth rate, etc.). Selection for these traits will increase production, but not necessarily productivity or efficiency of production. Measurements are thus required that express performance per constant (standardized) unit. Selection for productivity and efficiency, for instance, will have a permanent mitigating effect on the production of GHGs, as higher productivity will lead to higher gross efficiency as a result of diluting the maintenance cost of animals (Wall et al., 2010; Scholtz et al., 2011). Proper trait definition is therefore important.

In Africa, most meat-producing ruminants (e.g. cattle, sheep) are kept under extensive production systems and utilize the natural vegetation that mono-gastric animals are unable to digest. In the mature cow for example maintenance requirements represent $70 \%$ of her feed expenses (Ferrell, 1988), and the average feed cost per cow is $42 \%$ of the total annual production cost (McGrann, 1999). It is therefore important to select meat-producing ruminants that will convert the natural vegetation into high-quality protein for human consumption. In this system, a breeding objective should include improved cow/ewe fertility, cow/ewe efficiency, post weaning growth and efficiency and better adaptation to heat stress and poor nutritional environments.

Research has been conducted on the development of EBVs for cow maintenance requirements (Evans, 2001), but their interpretation and implementation may be a challenge (Evans et al., 2002). In a study by Olivier et al. (2001) it was indicated that the reproductive performance of ewes, defined as total weight of lamb weaned per ewe joined (TWW), can be genetically improved by direct or indirect selection. This suggests that in beef cattle, selection for weight of calf weaned per large stock unit (LSU) should be investigated as a means of improving cow efficiency. Although selection for number of days to calving was proposed some time ago, and seems to be an effective way of improving fertility in beef cattle (Johnston \& Bunter, 1996), its application is still limited in developing countries, since adequate data are not recorded by farmers.

In the post-weaning phase, breeding programmes focus on growth and efficiency traits. Selection for (lower) residual feed intake (RFI) differs from other feed efficiency traits such as feed conversion ratio (feed intake/growth) and feed efficiency (growth/feed intake), since it is independent of growth and body weight, thus it does not lead to increased maintenance requirements in mature animals. Residual feed intake is improved by reducing feed intake whereas feed conversion ratio can be improved by either better growth or lower levels of intake or both (Hendriks et al., 2013a; b). It will also lead to less methane emissions since a positive correlation exists between RFI and enteric methane production, thus reducing the carbon footprint (Nkrumah et al., 2006).

Following the suggestion to use residual feed intake (Arthur et al., 1996) as a measure of efficiency, MacNeil et al. (2011) proposed the use of residual daily gain (RDG) as an alternative. Both RFI and RDG hold benefits as efficiency traits, where RFI will decrease intake without affecting growth, and RDG will improve growth without affecting feed intake (Hendriks et al., 2013b). Evaluation of candidate animals for selection based on RFI and RDG provide quite different rankings of their merit (MacNeil et al., 2013) and the use of a selection index is an efficient approach to breaking this antagonism. An alternative may therefore be to apply economic weights to the EBV for ADG (average daily gain) and DFI (daily feed intake) directly, since this is straightforward and likely to be more transparent to farmers when compared with selection indices using residual measures of efficiency. MacNeil et al. (2013) therefore recommended that genetic evaluation systems should include analyses of the primary traits, ADG and DFI.

Bivariate methods to estimate protein (muscle) and adipose (fat) deposition efficiencies have been developed recently (Roux, 2006; 2009). This implies that in future it may be possible to select animals for efficiency of fat deposition and/or efficiency of muscle growth. To that effect, normal growth measurements (weight and gain) and measurements of feed intake and body composition between two growth points will be required. Whereas individual feed intake is already measured in some testing stations, body composition can be derived from real-time ultrasound scanning. 
The profitability of sheep enterprises is dependent on two factors: first, the productivity (output) of the enterprise, which can be increased through selection and, second, reduction of input costs (Rauw et al., 1998; Snowder \& Van Vleck, 2003). The breeding goal should therefore be to increase economic production efficiency (Luiting, 1990), which means that animals should be identified with high productivity and relatively low feed intake. This entails the improvement of the efficiency of sheep to convert the available herbage into products, which is the primary limiting factor in the extensive farming areas of South Africa (Herselman \& Olivier, 2010). Selection based on productivity will lead to animals and populations that are not only effective in using the natural resources optimally, but are adapted to harsh environments, thereby assisting in increasing meat production in these environments (Shrestha \& Fahmy, 2005).

Breeding objectives for small stock production differ from breed to breed, country to country and even from farm to farm. However, reproduction (ewe productivity) and its components are the traits that are universally important, because performance in these two traits define the efficiency and profitability of a sheep enterprise (Snyman et al., 1997; Olivier et al., 2001; Lupton, 2008). The biggest single opportunity for increasing the efficiency of lamb meat production is through an increase in the number of lambs marketed per ewe per year (Shelton, 1971).

In a study on South African Merino sheep, a 1.9\% increase per annum in total weaning weight (TWW) was achieved when selection was aimed at increasing reproduction rate (Cloete et al., 2004). Several other South African studies on sheep supported the fact that selection for reproduction can improve the net reproduction rate of a sheep farm (Snyman et al., 1997; Olivier et al., 1998; 2001). The conclusions from these South African studies are supported by studies done abroad. Selection of replacement animals (rams and ewes) on TWW resulted in an increase of $0.69 \mathrm{~kg}$ per year in litter weight weaned per ewe (Ercanbrack \& Knight, 1998). Burfening et al. (1993) reported that a favourable response in Rambouillet sheep was achieved over an 18-year period when selection was based on a reproductive index for number of lambs born. Although only a slight improvement in litter size and weight was achieved over a 30-year period for Targhee sheep, the authors concluded that the response represented a potentially significant economic advantage (Sakul et al., 1999).

Traditional breeding objectives for dairy cattle assume that an increase in individual production will be followed by a rise in the economic margin per animal if maintenance requirements continue to decline as a proportion of the total. This is acceptable only if selection for production maintains or increases feed efficiency and product quality, which may not be true (McManus, et al., 2013). There is evidence that selection for milk yield increases both feed intake and mobilization of body reserves in support of higher milk production and results in poorer female fertility in dairy cattle, probably as a result of a negative energy balance (Marie-Etancelin et al., 2002; Veerkamp et al., 2003). Although positive trends for milk production have been demonstrated several studies show negative results for protein and fat percentages (McManus et al., 2013).

Breeding for increased milk production was also found to have negative side effects on health and fertility (Pryce et al., 2004; de Jong, 2007), including an increase in the number of days to first service, number of days open, calving interval, and decreases in conception and pregnancy rates (Washburn et al., 2002; Rajala-Schultz \& Frazer, 2003). However, this is dependent on the level of milk production. For example, increasing milk yield from $5000 \mathrm{~kg}$ to $7000 \mathrm{~kg}$ per lactation would not have the same negative effect as when milk yield increases from $8000 \mathrm{~kg}$ to $10000 \mathrm{~kg}$ or higher. Few Holsteins cows in the United States currently survive beyond fifth parity, and average lifetime parity over the past 20 years has fallen from 3.4 to only 2.8 (Tsuruta et al., 2005). A study of the erosion rate of South African Jersey cattle indicated that their productive herd life declined from 7.9 lactations in 1970 to 2.3 lactations in 2003 (Du Toit et al., 2004).

In South Africa, the two main production systems in dairy cattle are where the cows are fed a total mixed ration, and where cows are milked from pastures. In a recent study, Neser et al. (2013) found a significant genotype $\mathrm{x}$ environment interaction between the two production environments for both milk production and age at first calving. The large interaction for reproduction in particular indicates that it may be important to follow a different approach when selecting bulls for the various production systems.

Breeding objectives for dairy cattle in many countries have focused on production traits, but this has changed in recent years, leading to more balanced breeding objectives comprising a wider range of economically important traits. The degree of emphasis placed on the various traits is highly variable among countries. Although efforts have been made to apply multiple trait selection indices in South African dairy cattle, there is a big need to objectively and systematically identify the traits that are desirable to improve, as 
well as their relative economic importance (Banga, 2009). A breeding objective should ideally include all economically relevant traits. Although their economic values have been determined, live weight and longevity cannot currently be included in a breeding objective for South African dairy breeds, as they are not routinely recorded and evaluated under the national genetic evaluation programme. The measurements of traits related to animal welfare (hoof problems, lameness, laminitis), heat stress and methane emissions of dairy cows are not catered for in the South African dairy industry either.

\section{Genomics}

Recent publications have indicated that the inclusion of information from DNA analysis in the genetic evaluations or estimation of breeding values in dairy cattle will have a great impact in dairy cattle breeding as it will increase the accuracies of breeding values of young bulls and decrease the generation interval (VanRaden et al., 2009, MacDonald \& Rickards, 2013; Van Marle-Köster et al., 2013). Strategies that utilizes EBVs derived from DNA information (genomic EBVs), together with conventional mixed model methodology, may speed up the process of breeding animals that are adapted to the newly created environments, as a result of climate change.

However, in beef cattle breeding (and small stock) some challenges must be addressed before any substantial gains can be expected from genomic EBVs. Worldwide, the dairy industry is dominated by two breeds and information is shared for example through INTERBULL, which is the body responsible for international genetic evaluation of dairy cattle (Mostert, 2007). In beef breeds, most countries have a large variety of breeds that make a significant contribution to the industry, but most of these breeds do not have the resources to genotype sufficient numbers to render genomic EBVs (MacDonald \& Rickards, 2013) of sufficient accuracy to accelerate genetic improvement in beef breeding programmes. Another challenge facing the beef industry is the limited recording of performance traits (Van Marle-Köster et al., 2013).

Since it is important to obtain a threshold number of records to make progress with genomic selection, international collaboration between societies in different countries is essential. In South Africa, the challenge is to collect a sufficient number of genotype and phenotype records for the country's Landrace breeds, especially for traits that are difficult or expensive to measure. Furthermore, these Landrace breeds and other tropical breeds need to be sequenced to allow for appropriate calibrations and subsequent development of the appropriate SNP chip for local use. At present, the chips that are available are adequate for studies on taurine breeds, but contain less information for Zebu or Landrace breeds (indigenous Sanga or locally developed breeds). Currently a significant number of markers cannot be used for Zebu or Landrace breeds, as they are fixed for the specific breed or show minor allele frequency (MAF) close to zero (Scholtz et al., 2011). In addition, Makina et al. (2013) reported that the Landrace, Bonsmara and Nguni breeds in South Africa appear to have substantially lower levels of linkage disequilibrium than that observed in the Holstein and Angus breeds, using the Bovine SNP50 BeadChip. This information will have significant implications for the design and application of marker association studies in South African cattle populations.

Since developments in quantitative trait loci (QTL) and genomic selection based on SNPs will enhance the detection and fine mapping of many genes and QTLs, it is foreseen that this will play a major role in selection for disease and parasite resistance or tolerance (Scholtz et al., 2010). Marker-assisted selection and proteomics may also be valuable in selection for secondary traits linked to adaptation, such as the gene(s) for high levels of blood urea $(\mathrm{N})$ and ruminal ammonia $\left(\mathrm{NH}_{3}\right)$ in certain genotypes, associated with adaptation to low-quality $\mathrm{C}_{4}$ grasses. Traits associated with the measurement of individual feed intake, meat quality, milk composition, disease resistance/tolerance, etc., may be expensive and/or difficult to measure, which also makes them ideal candidates for marker-assisted selection.

\section{Epigenetics}

All alterations in DNA function without alterations in DNA sequence are referred to as epigenetics. These include events associated with differentiation and development, as well as changes associated with gene expression and the expression of different phenotypes (appearance) and are mediated through a variety of mechanisms (Tollefsbol, 2004). These modifications are influenced by factors that are of environmental origin independent of DNA sequence, and the induced changes can be transferred to the progeny. Climate, temperature, nutrition, disease and other environmental factors can all "modify" the phenotypic expression of the genome of the animal through epigenetic mechanisms. A modern definition of epigenetics is "collective heritable changes in phenotype that arise independent of genotype” (Tollefsbol, 2011). 
It is postulated that if the survival of the parents was influenced or restricted by environmental factors, the offspring are pre-programmed with the information required to enable them to survive in a similar unfavourable environment. However, if the environment is different from the predicted one, the mismatch may result in mal-adaptation. This concept forms the basis of nutrigenomics, where the existence of nutrition-epigenetic-phenotype relationships in livestock is increasingly being researched and exploited ( $\mathrm{Li}$ et al., 2008; Neibergs \& Johnson, 2012).

Animal tradition (behaviour transferred to the progeny) is a different form of epi-mutation and is acquired by the animal through a learning process, for example by observing a parent or parental influence (Lambert \& Kingsley, 2012) and the nature of parental stimuli (Kurian et al., 2010). Mothering ability in livestock is of critical importance to the survival of the young and is included in many performance recording programmes, for example the estimation of maternal breeding values for weaning weight in beef cattle. The extent to which this and other behavioural traits in livestock are influenced by epigenetic factors, requires further investigation.

Although currently there is no direct evidence for epigenetic inheritance in dairy cows, simple additive genetic effects cannot account all of the variation in some of the dairy traits. This deficit is probably because of epigenetic influences within and between generations (Singh et al., 2012). Understanding the extent and scope of these mechanisms could provide opportunities to enhance milk production and mastitis resistance through manipulation of the environment while in utero or by manipulating early life nutrition. A recent study (Waddams et al., 2013) suggested that the conditioning of the rumen early in an animal's life will be carried over to its later life. This can have an effect on the microbial populations in the rumen and on the outputs of rumen fermentation (e.g. methane) in later life, which could lower the environmental impact from ruminant livestock.

Traditional breeding focuses on Mendelian inheritance and involves long term-breeding programmes. However, genetic and epigenetic controls influence genetic expression and should be taken into account when formulating breeding programmes for changing environmental conditions. Knowledge of epigenetic controls in the diverse environments of developing countries should allow for more effective control and management of such effects. Taking control of genetics, independent of Mendelian inheritance, can move the impact of climate change in future breeding beyond simple breeding programmes, and provide new management and nutritional tools to enhance productivity. This can be done by using the environment and management to define epigenetic controls, as well as nutritional interactions. This brings about the concept of "flash evolution", which can be defined as fast changes. The challenge is therefore to use "soft" or epigenetic inheritance to fine-tune the next generation more rapidly to novel environments than the slow reactivity of Mendelian or "hard inheritance".

\section{Appropriate genotypes and production systems}

Developing countries have to enhance the competitiveness of their livestock industries in national and international markets. In the southern African countries, the various types of indigenous Sanga cattle and small stock breeds should form the basis for increased productivity and product quality (Lepen 1996a; 1996b; Mpofu, 2002; Scholtz \& Theunissen, 2010).

In beef cattle, it is anticipated that indigenous breeds will be used increasingly as dam lines, as they mostly have small frames with lower feed requirements, good maternal abilities and low birth weights and mortality at birth. Some of these breeds have high calving rates as an outstanding feature (Schoeman, 1989), are adaptive to harsh environments (Bonsma, 1980; Scholtz, 1988), and have good meat quality characteristics (Strydom, (2008).

Many studies have shown that the efficiency of beef production in indigenous Sanga breeds can be increased when economic important traits are maximized through heterosis (Hetzel, 1988; Schoeman, 1989; Theunissen, 2011). Crossbreeding systems are generally employed for this purpose and to improve adaptation in exotic breeds. The study by Theunissen (2011) provided information on the effects of heterosis on production traits, using the Afrikaner as the dam line and European (Charolais and Simmentaler), British (Hereford) and Zebu (Brahman) breeds as sire lines. Results confirmed the Afrikaner's potential as a dam line. Similarly, other studies (Scholtz \& Lombard, 1992; Schoeman et al., 1993; Lepen, 1996; Moyo, 1996) suggest the use of appropriate genotypes to increase production efficiency in beef cattle. Mokolobate et al. (2013b) have shown that the kilogramme calf weaned per large stock unit can be increased by up to $21 \%$ 
through properly designed sustainable crossbreeding systems, thereby increasing cow efficiency and reducing the carbon footprint per unit product of beef production.

The effects of genetic heterozygosity tend to be large for traits with a low heritability such as fitness. In itself, fitness includes many components, such as pregnancy rate, prenatal survival and postnatal survival (mothering ability), which determines weaning rate. Breeding systems should be based on consideration of all components of weaning rate. Research by Theunissen et al. (2013) indicated that the fitness of crossbred females in two- and three-breed rotational crosses with British and European sires, while maintaining at least 25\% Sanga germplasm, exceeded that of their straight-bred contemporaries. Similarly, the direct and maternal heterosis effects on pre- and post-weaning weight traits were positive. Here the influence of direct heterosis effects of Zebu and maternal heterosis effects of Taurus breeds on the Sanga (Afrikaner) were noted.

Genetic heterozygosity probably also enhances resistance of hosts to infectious diseases, but tests to that effect are limited. Penn et al. (2002) challenged mice with multiple strains of Salmonella and one of Listeria and found that heterozygotes had greater survival and weight gain and were more likely to clear chronic Salmonella infection than homozygotes. They concluded that heterozygotes were more resistant than the average of parental homozygotes (dominant) and even more resistant than the parent with the highest resistance (overdominance). The role of crossbreeding for immune recognition of pathogens and parasites has apparently not been investigated in cattle.

With the impact of climate change, economic crossbreeding will rely heavily on dam breeds with low input costs, but also on sire breeds that are appropriate for the ultimate use of progeny that optimize the production from the dam line (Weaber, 2010). Terminal, rotational and roto-terminal crossing can become more regular breeding practices. Relative to F1 terminal crossing at 100\%, two- and three-breed rotational crossbreeding systems offer less expected hybrid vigour (approximately 66 and 86\%) with considerable variation in level of performance among cows and calves. Three-breed specific or terminal crosses maximize both individual and maternal heterosis. These latter systems are difficult to accomplish in small herds, which may have the option of only one or two breeding groups. Bulls that are rotated will have to possess maternal traits, as well as growth and carcass traits, since replacement heifers are retained in the herd.

Hybrid or composite bulls offer an easier alternative method of rotational crossbreeding and maintain hybrid vigour at a high level. Using F1 bulls on unrelated purebred cows will maximize direct heterosis without having the sometimes negative maternal heterosis effects of crossbred females on certain traits, for example the increased cow weight of replacement heifers bred from certain crossbred cows. F1 bulls consisting of the same two breeds as the crossbred cow herd, but unrelated, can retain $50 \%$ of maximum possible heterosis. Composite bulls also offer heterosis with the amount depending on the original breed composition and the possible partial loss from inbreeding in the breed, and the relationship with the dam line (Lamberson et al., 1993). In these systems, the germplasm of the cow herd can be conserved/maintained and genetic progress can be made when the best portion of cows are mated to bulls of the same breed to $\mathrm{p}$ replacement heifers (Scholtz \& Theunissen, 2010). Fitness and weight traits can simultaneously be improved when Taurus $\mathrm{x}$ Indicus sires are used. The additive genetic merits of the breeds that are used in the crossbreeding systems ultimately remain very important (Craig, 2011).

With regards to crossbreeding Southern African countries have a challenge to develop multi-breed genetic evaluations to better evaluate composite breeds and to accommodate the evaluation of crossbred beef cattle, especially bulls.

\section{Breeding objectives for emerging/subsistence farmers}

The livestock industries in developing countries are highly dualistic with commercial, emerging and communal sectors (subsistence or small-scale farmers) all co-existing. While the off-take (slaughter rate) from the commercial sector is at an acceptable level, the off-take from the other sectors is still low in certain countries as a result of low fertility and high mortality; which are mainly the result of diseases and parasites, lack of feed resources and poor rangeland management (Chimonyo et al., 2000; Montshwe, 2006; Musemwa et al., 2007). The major discrepancies in production and throughput between the various sectors are linked to aspects such as pre-weaning mortality, herd composition and calving percentage (Scholtz \& Bester, 2010). Only when these management factors are addressed will the formulation of breeding objectives/strategies have an impact in the emerging and communal sectors. 
Furthermore, subsistence farmers in Africa keep livestock for multiple purposes and rural households depend on livestock for milk, meat, hides, horns, fertilizer and income (Chimonyo et al., 1999; Dovie et al., 2006). Livestock is therefore central to the livelihoods and wellbeing of rural communities. This makes performance recording difficult since the breeding objectives may include many traits, some of which cannot be easily measured or quantified, as they are related to social or cultural practices (Scholtz et al., 2011). The formulation of breeding objectives and strategies will somehow have to take these dynamics into consideration.

\section{Conclusions}

The ways in which livestock are bred, as well as livestock production systems, have changed drastically in the twentieth century. The human population explosion gave rise to widespread competition with other species and other uses for agricultural land, and influenced the environment in which livestock are raised. This resulted in intensification of production, changes in production systems and in the breeds used. In addition, climate change will result in increases in the frequency of heat stress, droughts and floods, which will have adverse effects on livestock production.

It will become more important to match the genotype to the environment to ensure a sustainable increase in production, to define breeding objectives, and to develop appropriate selection criteria to ensure that breeding is effective and aimed at sustainable production in changing environments. Most animal breeding programmes lack basic definition of breeding objectives and criteria that can be used. In developing countries, maximum production as an outcome may not be feasible or the recommended production system, which is in contrast to livestock production systems in developed countries in the northern hemisphere temperate zone. Systems of optimal production that are in harmony with the environment and that utilize appropriate genotypes should be developed where they are not already in place. These should include the definition of breeding objectives that can be linked to tangible and intangible factors of sustainability of production systems in changing environments.

The last two decades have been marked by the development of advanced technologies and knowledge, for example genomics and epigenetics. To fully benefit from these technologies, performance and pedigree recorded herds of local breeds in developing countries, especially sub-Saharan Africa countries, have to participate in ongoing SNP genotyping and sequencing. This will allow for effective calibration and development of the appropriate chips that contain adequate information for the local breeds, breed combinations, production systems and resistance/tolerance to livestock diseases. More attention should be given to the selection environment and the environment in which the organism develops (e.g. in utero, in ovo, during neonatal growth, early life nutritional regime, climate) and are required to perform. The possibilities are huge and are likely to become more important as animals are pushed genetically to achieve higher levels of performance and efficiency.

Epigenetic mechanisms may explain why some breeding programmes, where pedigree populations are developed and selected in ideal environments (different from those in which their progeny are expected to perform), have been unsuccessful. Improved knowledge of epigenetic mechanisms may one day lead to close cooperation between primary breeders and target customers. Using proven quantitative breeding technology linked to genomic information may make it possible for primary breeders to select their pedigreed livestock, based on the performance of large numbers of final product grown in the production environment. With a better understanding of epigenetic mechanisms and close cooperation between primary breeders and their customers, it may be possible to tailor-make commercial livestock for different environments (specific nutrition, housing types, and climates), resulting in greatly improved production efficiencies.

\section{Acknowledgement}

This work is based on research supported in part by Red Meat Research and Development South Africa and the National Research Foundation of South Africa, under grant UID 75123. The grant holder acknowledges that opinions, findings and conclusions or recommendations expressed in any publication generated by NRF-supported research are those of the authors and the NRF accepts no liability whatsoever in this regard. 


\section{References}

Arthur, P.F., Herd, R.M., Wright, J., Xu, G., Dibley, K. \& Richardson, E.C., 1996. Net feed conversion efficiency and its relationship with other traits in beef cattle. Proc. Aust. Soc. Anim. Prod. 21, 107-110.

Banga, C.B., 2009. The development of breeding objectives for Holstein and Jersey cattle in South Africa. Ph.D thesis, University of the Free State, Bloemfontein, South Africa.

Bonsma, J.C., 1980. Livestock Production: A Global Approach. Tafelberg Publishers, Cape Town, South Africa.

Bourdon, R.M. \& Enns, R.M., 1998. Physiological breeding values: Rethinking the way we express genetic values for improving production systems. Proc. 6th Wrld. Cong. Genet. Applied Livest. Prod. 27, 227-234.

Burfening, P.J., Kachman, S.D., Hanford, K.J. \& Rossi, D., 1993. Selection for reproductive rate in Rambouillet sheep: estimated genetic change in reproductive rate. Small Rumin. Res. 10, 317-330.

Capper, J.L., 2013. Should we reject animal source foods to save the planet? A review of the sustainability of global livestock production. S. Afr. J. Anim. Sci. 43, 233-246.

Chimonyo, M., Kusina, N.T., Hamudikuwanda, H. \& Nyoni, O., 1999. A survey on land use and usage of cattle for draught in a smallholder farming area of Zimbabwe. J. Appl. Sci. Southern Afr. 5, 111-121.

Chimonyo, M., Kusina, N.T., Hamudikuwanda, H., Nyoni, O., \& Ncube, I., 2000. Effects of dietary supplementation and work stress on ovarian activity in non-lactating Mashona cows in a smallholder farming area of Zimbabwe. Anim. Sci. 70, 317-323.

Cloete, S.W.P., Gilmour, A.R., Olivier, J.J. \& Van Wyk, J.B., 2004. Genetic and phenotypic trends and parameters in reproduction, greasy fleece weight and live weight in Merino lines divergently selected for multiple rearing ability. Aust. J. Exp. Agric. 44, 745-754.

Craig, R., 2011. Crossbreeding and rotational systems for beef production. Available at: http://informedfarmers.com

De Jong, G., 2007. Usage of predictors for fertility in the genetic evaluation, application in the Netherlands. Available from: https://global.crv4all.com/68143/67761/67689/67751

Dovie, D.B.K., Shackleton, C.M. \& Witkowski, E.T.F., 2006. Valuation of communal area livestock benefits, rural livelihoods and related policy issues. Land Use Policy 23, 260-271.

Du Toit, J., Olivier, J.J. \& Van Wyk, J.B., 2004. An investigation into erosion rate of lactation records in South African Jersey cattle. Proc. $2^{\text {nd }}$ Joint Congr. Grassland Soc. and S. Afr. Soc. Anim. Sci., Goudini, South Africa. p. 118.

Els, D.L., 1988. Kruisteling vir vleisproduksie. PhD thesis, University of the Free State, South Africa.

Evans, J.L., Golden, B.L. \& Hough, B.L., 2002. A new genetic prediction for cow maintenance energy requirements. www.beefimprovement.org/proceedings/.../Evans_02BIF.pdf

Evens, L.J., 2001. Genetic prediction of mature weight and mature cow maintenance energy requirements in Red Angus cattle. PhD Colorado State University, Fort Collins, USA.

Falconer, D.S. \& MacKay, T.F.C., 1996. Introduction to Quantitative Genetics, 4th Ed. 1996. Longmans Green, Harlow, Essex, UK.

Ferrell, C.L., 1988. Contribution of visceral organs to animal energy expenditure. J. Anim. Sci. 66 (Suppl. 3), 23-34.

Food and Agriculture Organization (FAO). 1998. Secondary guidelines for development of national genetic resource management plans. pp. 53-62.

Gianola, D., 2006. Statistics in animal breeding: Angels and demons. Proc. $8^{\text {th }}$ Wrld Congr. Genet. Appl. Livest. Prod., August 13-18, 2006, Belo Horizonte, MG, Brazil. www.wcgalp8.org.br/wcgalp8/articles.

Hayes, B.J., Bowman, P.J., Chamberlain, A.J. \& Goddard, M.E., 2009. Invited review: Genomic selection in dairy cattle: progress and challenges. J. Dairy Sci. 92, 433-443.

Hendriks, J., Scholtz, M.M. \& Neser, F.W.C., 2013a. Possible reasons for differences in residual feed intake: An overview. S. Afr. J. Anim. Sci. 43, S103-S106.

Hendriks, J., Scholtz, M.M., Neser, F.W.C. \& Van Wyk, J.B., 2013b. Genetic parameters of feedlot traits in Angus cattle. Proc. $46^{\text {th }}$ Cong. S. Afr. Soc. Anim. Sci., University of the Free State, Bloemfontein. p. 97. 
Herselman, M.J. \& Olivier, W.J., 2010. Description of a model for the calculation of breeding values for profitability. Grootfontein Agric. 10, 67-75.

Hetzel, D.J.S., 1988. Comparative productivity of the Brahman and some indigenous Sanga and Bos indicus breeds of East and Southern Africa. Animal Breeding Abstracts 56, 243-255.

Holst, P.J., 1999. Recording and on-farm evaluations and monitoring: breeding and selection. Small Rumin. Res. 34, 197-202.

Kosgey, I.S. \& Okeyo, A.M., 2007. Genetic improvement of small ruminants in low-input, smallholder production systems: Technical and infrastructural issues. Small Rumin. Res. 70, 76-88.

Lepen, J.M., 1996. Breed characterization studies in Namibia. www.nbri.org.na/old/agricola_files/ Agricola1996.

Linington, M.J., 1990. The use of Sanga cattle in beef production. In: Technical communication No 223, Department of Agriculture, South Africa. pp. 31-37.

Luiting, P., 1990. Genetic variation of energy partitioning in laying hens: causes of variation in residual feed consumption. Wrld's Poult. Sci. J. 46, 133-152.

Lupton, C.J., 2008. ASAS Centennial Paper: Impacts of animal science research on United States sheep production and predictions for the future. J. Anim. Sci. 86, 3252-3274.

MacNeil, M.D., Lopez-Villalobos, N. \& Northcutt, S.L., 2011. A prototype national cattle evaluation for feed intake and efficiency of Angus cattle. J. Anim. Sci. 89, 3917-3923.

MacNeil, M.D., Scholtz, M.M. \& Maiwashe, A., 2013. Estimates of variance components for postweaning feed intake and growth in Bonsmara bulls and evaluation of alternative measures of feed efficiency. S. Afr. J. Anim. Sci. 41, 18-24.

Makina, S.O., Maiwashe, A.N., Van Marle-Köster, E. \& Muchadeyi, F.C., 2013. Estimating the extent of linkage disequilibrium in four SA cattle breeds. Proc. 46th Cong. S. Afr. Soc. Anim. Sci., University of the Free State, Bloemfontein. p. 99.

Marie-Etancelin, C., Such, X., Barillet, F., Bocquier, F. \& Caja, G., 2002. Nutrition, alimentation et élevage des brebis laitières: mâýtrise de facteurs de production pour réduire les coûts et améliorer la qualité des produits. Options Méditerranéennes, 42 B, 57-71.

McDonald, A. \& Rickards, A., 2013. The potential for genomics in the beef cattle industry. S. Afr. Simbra J. 46-48.

McGrann, J.M., 1999. Cow-calf standardized performance analysis (SPA) in the southwest. Available: http://areoext.tamu.edu/spa/standperformance.htm

McManus, C., Piava, S., Seixa, L., Neto, J.B., Dallago, B.F.L., de Melo, C.B. \& Scholtz, M.M., 2013. Adaptations of cattle to stressful environments. In: Cattle: Domestication, Diseases and the Environment. Ed: Lui, G., USDA-ARS, ANRI, Bovine Functional Genomics Laboratory, Beltsville, USA, 139-158.

Mokolobate, M.C., Scholtz, M.M., Mulugeta, S. \& Neser, F.W.C., 2013a. Report on a breeding objective that may reduce the carbon footprint of extensive cow-calf production systems. Nat. Sci. 5, 167-171.

Mokolobate, M.C., Scholtz, M.M., Neser, F.W.C. \& Mulugeta, S.D., 2013b. Sustainable beef cattle crossbreeding systems in the era of climate change. Proc. 46th Cong. S. Afr. Soc. Anim. Sci., 78.

Montshwe, D.B., 2006. Factors affecting participation in mainstream cattle markets by small-scale cattle farmers in South Africa. MSc thesis, University of Free State, South Africa.

Mostert, B.E., 2007. The suitability of test-day models for genetic evaluation of dairy cattle in South Africa. PhD thesis, University of Pretoria, South Africa.

Musemwa, L., Chagwiza, C., Sikuka, W., Fraser, G., Chimonyo, M. \& Mzileni, N., 2007. Analysis of cattle marketing channels used by small scale farmers in the Eastern Cape Province, South Africa. Livest. Res. Rural Dev. 19, Article \#131. http://www.Irrd.org/lrrd19/9/muse19131.htm

Neser, F.W.C., Erasmus, G.J. \& Scholtz, M.M., 2008. The use of a cluster analysis in across herd genetic evaluation for beef cattle. S. Afr. J. Anim. Sci. 38, 51-57.

Neser, F.W.C., Van Wyk, J.B. \& Ducroc, V.L., 2013. A preliminary investigation into genotype $x$ environment in dairy cattle. Proc. $46^{\text {th }}$ Congr. S. Afr. Soc. Anim. Sci. University of the Free State, Bloemfontein. p. 204.

Nkrumah, J.D., Okine, E.K., Mathison, G.W., Schmid, K., Li, C., Basarab, J.A., Price, M.A., Wang, Z. \& Moore, S.S., 2006. Relationships of feedlot feed efficiency, performance, and feeding behavior with metabolic rate, methane production, and energy partitioning in beef cattle, J. Anim. Sci. 84, 145-153. 
Olivier, W.J., Snyman, M.A., Van Wyk, J.B. \& Erasmus, G.J., 1998. Genetic parameter estimates for fitness traits in South African Merino sheep. Livest. Prod. Sci. 56, 71-77.

Olivier, W.J., Snyman, M.A., Olivier, J.J., Van Wyk, J.B. \& Erasmus, G.J., 2001. Direct and correlated responses to selection for total weight of lamb weaned in Merino sheep. S. Afr. J. Anim. Sci. 31, 115-121.

Penn, D.J., Damjanovich, K. \& Potts, W.K., 2002. MHC heterozygosity confers a selective advantage against multiple-strain infections. Proc. of the National Academy of Sciences 99 (17), 11260-11264.

Ponzoni, R.W., 1986. Economic evaluation of breeding objectives in sheep and goats - summary and commentary. Proc. $3^{\text {rd }}$ WCGALP, 16-22 July 1986, Lincoln, Nebraska, USA, pp. 465-469.

Ponzoni, R.W., 1992. Genetic Improvement of Hair Sheep in the Tropics. FAO Anim. Prod. Health Paper 101, Rome, Italy, p. 168.

Prayaga, K.C., Barendse, W. \& Burrow, H.M., 2006. Genetics of tropical adaptation. Proc. 8th Wrld Congr. on Genet. Appl. Livest. Prod., August 13-18, 2006, Belo Horizonte, MG, Brazil. www.wcgalp8.org.br/wcgalp8/articles.

Pryce, J.E., Royalb, M.D., Garnsworthy, P.C. \& Mao, I.L., 2004. Fertility in the high-producing dairy cow. Livest. Prod. Sci. 86, 125-135.

Rajala-Schultz, P.J. \& Frazer, G.S., 2003. Reproductive performance in Ohio dairy herds in the 1990s. Anim. Reprod. Sci. 76, 127-142.

Rauw, W.M., Kanis, E., Noordhuizen-Stassen, E.N. \& Grommers, F.J., 1998. Undesirable side effects of selection for high production efficiency in farm animals: A review. Livest. Prod. Sci. 56, 15-33.

Roux, C.Z., 2006. Incorporating turnover in estimates of protein retention efficiency for different body tissues. Br. J. Nutr. 95, 246-254.

Roux, C.Z., 2009. Use of theoretical efficiencies of protein and fat synthesis to calculate energy requirements for growth in pigs. Br. J. Nutr. 101, 895-901.

Sakul, H., Bradford, G.E. \& Dally, M.R., 1999. Selection for litter size or weaning weight in range sheep. I. Selection practiced and direct response. Sheep Goat Res. J. 15, 126-137.

Schoeman, S.J., 1989. Recent research into production potential of indigenous cattle with special reference to Sanga (Review). S. Afr. J. Anim. Sci. 19, 55-61.

Schoeman, S.J., Van Zyl, J.G.E. \& De Wet, R., 1993. Direct and maternal additive and heterotic effects in crossbreeding Hereford, Simmentaler and Afrikaner cattle. S. Afr. J. Anim. Sci. 23, 61-71.

Schoeman, S.J., Cloete, S.W.P. \& Olivier, J.J., 2008. Returns on investment in sheep and goat breeding in South Africa. Livest. Sci. 130, 70-82.

Scholtz, M.M., 1988. Selection possibilities for hardy beef breeds in Africa: The Nguni example. Proc. $3^{\text {rd }}$ World Cong. Sheep and Beef Cattle Breed. 2, 303-319.

Scholtz, M.M. \& Lombard, P.E., 1992. Prospects and potential of Southern African cattle breeds: The Nguni example. Proc. Aust. Assoc. Anim. Breed. Genet. 10, 47-50.

Scholtz, M.M. \& Bester, J., 2010. Off-take and production statistics in the different South African cattle sectors: Results of a structured survey. Appl. Anim. Hus. \& Rural Dev. 3, 19-23.

Scholtz, M.M. \& Theunissen, A., 2010. The use of indigenous cattle in terminal cross-breeding to improve beef cattle production in Sub-Saharan Africa. Animal Genetic Resources Information 46, 33-36.

Scholtz, M.M., Furstenburg, D., Maiwahse, A., Makgahlela, M.L., Theron, H.E. \& Van der Westhuizen, J., 2010. Environmental-genotype responses in livestock to global warming: A Southern African perspective. S. Afr. J. Anim. Sci. 40, 408-413.

Scholtz, M.M., McManus, C., Okeyo, A.M. \& Theunissen, A., 2011. Opportunities for beef production in developing countries of the southern hemisphere. Livest. Sci. 142, 195-202.

Scholtz, M.M., Steyn, Y., Van Marle-Köster, E. \& Theron, H.E., 2012. Improved production efficiency in cattle to reduce their carbon footprint for beef production. S. Afr. J. Anim. Sci. 42, 450-453.

Scholtz, M.M., McManus, G., Leeuw, K-C., Louvandini, H., Seixas, L., Demelo, C.B., Theunissen, A. \& Neser, F.W.C., 2013a. The effect of global warming on beef production in developing countries of the southern hemisphere. Nat. Sci. 5, 106-119.

Scholtz, M.M., Nengovhela, N.B., McManus, C., Theunissen, A. \& Okeyo, A.M., 2013b. Political, economic and social challenges for beef production in southern Africa. In: Developing Countries: Political, Economic and Social Issues, Eds: Ramazzotti, A. \& Gravina, W., Nova Publishers. pp. 97-118. 
Shelton, M., 1971. Some factors affecting efficiency of lamb production. Texas Agric. Exp. Sta. Tech. Rep. No. 26.

Shrestha, J.N.B. \& Fahmy, M.H., 2005. Breeding goats for meat production: a review 1. Genetic resources, management and breed evaluation. Small Rumin. Res. 58, 93-106.

Simm, G., Conington, J., Bishop, S.C., Dwyer, C.M. \& Pattinson, S., 1996. Genetic selection for extensive conditions. Appl. Anim. Behav. Sci., 49, 47-59.

Snowder, G.D. \& Van Vleck, L.D., 2003. Efficiency of postweaning growth in lambs: Estimates of genetic parameters and selection strategies to improve the economic efficiency of postweaning growth in lambs. J. Anim. Sci. 81, 2704-2713.

Snyman, M.A., Erasmus, G.J., Van Wyk, J.B. \& Olivier, J.J., 1997. Genetic parameter estimates for total weight of lamb weaned in Afrino and Merino sheep. Livest. Prod. Sci. 48, 111-116.

Strydom, P.E., 2008. Do indigenous South African cattle breeds have the right genetics for commercial production of quality meat? Meat Sci. 80, 86-93.

Theunissen, A., 2011. Charaterization of breed additive and heterosis effects in beef cattle using experimental results. M.Sc. thesis. University of the Free State, Bloemfontein, South Africa.

Theunissen, A., MacNeil, M.D., Scholtz, M.M. \& Neser, F.W.C., 2013. Crossbreeding to increase beef production: Additive and non-additive effects on fitness traits. S. Afr. J. Anim. Sci. 43, Submitted.

Tsuruta, S., Misztal, I. \& Lawlor, T.J., 2005. Changing the definition of productive life in US Holsteins: effect on genetic correlations. J. Dairy Sci. 88, 1156-1165.

Van der Westhuizen, J., 2002. Why a scientifically based central database for South Africa? The Intergis puts South African livestock producers at the same level as the world finest. In: The cutting edge of research and development innovations in beef cattle. ARC, Irene, South Africa. pp. 43-48.

Van der Westhuizen, J., Scholtz, M.M. \& Mamabolo, M.J., 2005. Importance of infrastructure and system for livestock recording and improvement in developing countries. Proc. $4^{\text {th }}$ All Africa Conf. and Anim. Agric. $31^{\text {st }}$ Meeting of Tanz. Soc. Anim. Prod. pp. 345-350.

Van Marle-Köster, E., Visser, C. \& Berry, D.P., 2013. A review of genomic selection - Implications for the South African beef and dairy cattle industries. S. Afr. J. Anim. Sci. 43, 1-17.

Van Raden, P.M., Van Tassell, C.P., Wiggans, G.R., Sonstegard, T.S., Schnabel, R.D., Taylor, J.F. \& Schenkel, F.S., 2009. Invited Review: Reliability of genomic predictions for North American Holstein bulls. J. Dairy Sci. 92, 16-24.

Veerkamp, R.F., Beerda, B. \& Van der Lende, T., 2003. Effects of genetic selection for milk yield on energy balance, levels of hormones, and metabolites in lactating cattle, and possible links to reduced fertility. Livest. Prod. Sci. 83, 257-275.

Waddams, K.E., McEwan, N.R., Yanez-Ruiz, D.R. \& Newbold, C.J., 2013. The potential of dietary manipulation in early life to decrease methane production by lambs later in life. Adv. Anim. Biosci. 4, 270.

Wall, E., Simm, G. \& Moran, D., 2010. Developing breeding schemes to assist mitigation of greenhouse gas emissions. Animal 14, 1-11.

Washburn, S.P., Silvia, W.J., Brown, C.H., McDaniel, B.T. \& McAllister, A.J., 2002. Trends in reproductive performance in South-Eastern Holstein and Jersey DHI herds. J. Dairy Sci. 85, 244-251.

Weaber, B., 2010. Crossbreeding for commercial beef production. In: Beef sire selection manual. $2^{\text {nd }}$ ed. http://www.ca.uky.edu/agcomm/PUBS/ASC/asc169. 